\title{
Assessment of platelet function in patients with Raynaud's syndrome
}

\author{
RA HUTTON, DP MIKHAILIDIS, ${ }^{*}$ RM BERNSTEIN, $\dagger$ JY JEREMY,${ }^{*}$ GRV HUGHES, $\dagger$ \\ P DANDONA*
}

From the Haemophilia Centre, Department of Haematology, and ${ }^{*}$ Metabolic Unit, Department of Chemical Pathology, Royal Free Hosptial and School of Medicine, Pond Street, London, NW3 and †Rheumatology Unit, Royal Postgraduate Medical School, Hammersmith Hospital, Ducane Road, London W12

SUMmARY Platelet function was studied in 11 patients with Raynaud's syndrome and 11 healthy controls. Platelets obtained from patients with Raynaud's syndrome were significantly more responsive to adrenaline, produced more thromboxane $A_{2}$, and were resistant to prostaglandin inhibitors (prostacyclin and prostaglandin $E_{1}$ ) of platelet aggregation. Platelets from control subjects and patients with Raynaud's syndrome were more resistant to prostaglandin inhibitors when reactions were carried out at $27^{\circ} \mathrm{C}$ rather than at $37^{\circ} \mathrm{C}$. Patients with Raynaud's syndrome also had significantly increased plasma concentrations of $\beta$-thromboglobulin, fibrinogen, and circulating platelet aggregates. In an attempt to elicit local platelet responses, the forearms of control subjects and patients with Raynaud's syndrome were cooled in water tanks and platelet function tests performed before and after cooling. No significant difference in the results was observed.

The potential role of platelets in the pathogenesis of Raynaud's syndrome is discussed.

Raynaud's phenomenon is characterised by reduced blood flow in peripheral vessels precipitated by cooling and is sometimes complicated by local ischaemic lesions. ${ }^{1-3}$ To account for this condition, it has been proposed that a functional imbalance develops between prostacyclin and thromboxane $A_{2}$ : the former is a potent vasodilator and inhibitor of platelet aggregation synthesised by vascular endothelium, ${ }^{4}$ while the latter is a vasoconstrictor generated by activated platelets and has proaggregatory properties. $^{5}$

We have previously shown that platelets from normal subjects are significantly less sensitive to the in vitro antiaggregatory action of prostacyclin at temperatures below $37^{\circ} \mathrm{C} .^{67}$ The activity of other antiaggregatory prostaglandins was similarly reduced. ${ }^{67}$

Since such changes might contribute to the vasoocclusive events which are characteristic of Raynaud's phenomenon, we have examined the effect of cooling on platelet function and its inhibition by prostaglandins in a group of patients with this disorder.

Accepted for publication 25 October 1983

\section{Material and methods}

IN VITRO STUDIES

Patients and controls

Eleven patients (four men, seven women; median age 38 years, range 19-58 years) were studied. Three patients had primary Raynaud's disease, while eight had Raynaud's syndrome secondary to mixed connective tissue disease (three cases), CREST variant of scleroderma (four cases), or systemic lupus erythematosus (one case). Four patients were receiving oral prednisolone (5-10 mg daily). None had ingested any other drugs for at least two weeks before testing. Patients with blood platelet counts below $100 \times 10^{9} / 1$ were excluded.

Eleven normal subjects (four men, seven women; median age 34 years, range $22-47$ years) who had not ingested any drugs for two weeks before sampling were selected as controls. None had any clinical evidence of Raynaud's syndrome.

\section{Collection of samples}

All venous blood samples were collected through a 21 gauge butterfly needle (Abbot, Ireland Ltd, Sligo, Eire) using a two syringe technique and discarding the first $5 \mathrm{ml}$. 
Tests carried out on blood samples

Platelet aggregation. Blood for platelet aggregation studies was collected in $1 / 10$ volume of $3.8 \%$ trisodium citrate. Samples were collected after an overnight fast. The tourniquet was released once successful venepuncture was achieved. The first 5-10 ml collected was either discarded or used for tests other than platelet function tests. Platelet rich plasma and platelet poor plasma were prepared by centrifugation as previously described. ${ }^{7}$ Platelet aggregation studies were carried out at $27^{\circ} \mathrm{C}$ and $37^{\circ} \mathrm{C}$ in Payton dual channel aggregometers.

Platelet aggregation was expressed as the percentage fall in optical density $3 \mathrm{~min}$ after the addition of aggregating agents (adenosine diphosphate (ADP); adrenaline; collagen; ristocetin). ${ }^{7}$ ADP and adrenaline were obtained from Sigma Chemicals (Poole, UK); collagen from Hormon-Chemie (Munich, Germany); and ristocetin from Lundbeck (Copenhagen, Denmark). The concentrations of agonists used are shown in Tables 1 and 2 .

Since the platelet counts (determined by standard visual techniques) were often lower in patients than in controls, the platelet counts in the controls were reduced (by adding platelet poor plasma) before inducing aggregation. These counts were adjusted so that they did not differ by more than $\pm 50 \times 10^{9} / 1$ from the appropriate count in the patient's platelet rich plasma.

Thromboxane $B_{2}$ release from platelets. Platelet aggregation was induced by the addition of ADP (final concentration $10 \mu \mathrm{mol} / \mathrm{l}$ ) or collagen (final concentration $1 \mu \mathrm{g} / \mathrm{ml}$ ) as described above. After 3 min the platelet rich plasma was added to ethanol to stop the reaction and the sample was frozen at $-70^{\circ} \mathrm{C}$ until the time of assay of thromboxane $\mathrm{B}_{2}$ (the sponaneous, stable metabolite of thromboxane $\mathrm{A}_{2}$ ), which was performed by a specific radioimmunoassay technique.

Inhibitory effect of prostacyclin and prostaglandin $E_{1}$ on platelet aggregation. Prostacyclin and prostaglandin $E_{1}$ were gifts from Dr J Pike, Upjohn Ltd, Kalamazoo, Michigan, USA. Both prostaglandins were dissolved in ethanol before dilution in Tris buffered saline (TBS), pH 8.0 as described previously.? Platelet rich plasma was incubated for $1 \mathrm{~min}$ at $27^{\circ} \mathrm{C}$ or $37^{\circ} \mathrm{C}$ with various concentrations of the two prostaglandins. Incubation with TBS (with the appropriate volume of ethanol added) alone acted as a control. After this incubation ADP (final concentration $10 \mu \mathrm{mol} / \mathrm{l})$ was added. Aggregation was calculated as described above, and the amount of inhibition induced by the prostaglandin was determined using the calculation:

$\%$ inhibition $=$

$\%$ aggregation with TBS - \% aggregation with prostaglandin aggregation with TBS

Plasma fibrinogen concentrations. Platelet poor plasma fibrinogen concentrations were determined using a gravimetric method. ${ }^{8}$

Table 1 Platelet function tests in patients with Raynaud's syndrome and in control subjects

\begin{tabular}{|c|c|c|c|c|c|c|c|c|c|c|}
\hline & \multicolumn{2}{|c|}{ Platelet count $\left(10^{\circ} / l\right)$} & \multicolumn{6}{|c|}{ Platelet aggregation $(\%)^{*}$} & \multirow{3}{*}{$\begin{array}{l}\text { Plasma } \beta- \\
\text { thrombo- } \\
\text { globulin } \\
\text { (ng/ml) }\end{array}$} & \multirow{3}{*}{$\begin{array}{l}\text { Plasma platele } \\
\text { factor } 4 \\
\text { (pmol/ml) }\end{array}$} \\
\hline & \multirow[t]{2}{*}{ Blood } & \multirow[t]{2}{*}{$P R P$} & \multicolumn{2}{|c|}{$A D P(\mu \mathrm{mol} / \mathrm{l})$} & \multicolumn{2}{|c|}{ Adrenaline ( $\mu \mathrm{mol} / \mathrm{l}$ ) } & \multirow{2}{*}{$\begin{array}{l}\text { Collagen } \\
(1 \mu g / m l)\end{array}$} & \multirow{2}{*}{$\begin{array}{l}\text { Ristocetin } \\
(1 \mathrm{\mu g} / \mathrm{ml})\end{array}$} & & \\
\hline & & & 0.5 & $2 \cdot 0$ & 0.5 & $2 \cdot 0$ & & & & \\
\hline $\begin{array}{l}\text { Patients } \\
\text { Controls }\end{array}$ & $\begin{array}{l}164 \\
(101-274) \\
245 \\
(179-262)\end{array}$ & $\begin{array}{l}244 \ddagger \\
(140-462) \\
419 \\
(301-503)\end{array}$ & $\begin{array}{l}13 \\
(0-35) \\
8 \\
(0-33)\end{array}$ & $\begin{array}{l}70 \\
(20-88) \\
73 \\
(60-90)\end{array}$ & $\begin{array}{l}75 \dagger \\
(3-90) \\
28 \\
(11-69)\end{array}$ & $\begin{array}{c}85 \\
(8-90) \\
70 \\
(59-88)\end{array}$ & $\begin{array}{l}70 \\
(3-95) \\
80 \\
(60-90)\end{array}$ & $\begin{array}{l}88 \\
(3-95) \\
85 \\
(54-95)\end{array}$ & $\begin{array}{l}85 \ddagger \\
(25-200) \\
34 \\
(20-80)\end{array}$ & $\begin{array}{l}0.4 \\
(0-0.7) \\
0.3 \\
(0-0.6)\end{array}$ \\
\hline
\end{tabular}

PRP $=$ platelet rich plasma; ADP = adenosine diphosphate.

* Platelet counts were corrected as described in the methods section; †Patients $v$ controls, $\mathrm{p}<0.05$; $\$$ Patients $v$ controls, $\mathrm{p}<0.02$ (Mann-Whitney test). Results are expressed as median (range).

Table 2 Platelet aggregation at $37^{\circ} \mathrm{C}$ and $27^{\circ} \mathrm{C}$ in patients with Raynaud's syndrome and in control subjects

\begin{tabular}{|c|c|c|c|c|c|c|c|c|c|c|}
\hline & \multicolumn{2}{|c|}{$A D P(0.5 \mu \mathrm{mol} / \mathrm{l})$} & \multicolumn{2}{|c|}{$A D P(2 \mu \mathrm{mol} / \mathrm{l})$} & \multicolumn{2}{|c|}{ Adrenaline $(0.5 \mu \mathrm{mol} / \mathrm{l})$} & \multicolumn{2}{|c|}{ Adrenaline $(2 \mu \mathrm{mol} / \mathrm{l})$} & \multicolumn{2}{|c|}{ Collagen $(1 \mu \mathrm{g} / \mathrm{ml})$} \\
\hline & $37^{\circ} \mathrm{C}$ & $27^{\circ} \mathrm{C}$ & $37^{\circ} \mathrm{C}$ & $27^{\circ} \mathrm{C}$ & $37^{\circ} \mathrm{C}$ & $27^{\circ} \mathrm{C}$ & $37^{\circ} \mathrm{C}$ & $27^{\circ} \mathrm{C}$ & $37^{\circ} \mathrm{C}$ & $27^{\circ} \mathrm{C}$ \\
\hline $\begin{array}{l}\text { Patients } \\
\text { Controls }\end{array}$ & $\begin{array}{l}13 \\
(0-35) \\
8 \\
(0-33)\end{array}$ & $\begin{array}{l}34^{*} \\
\left(8^{8-58)}\right. \\
40^{*} \\
(12-58)\end{array}$ & $\begin{array}{l}70 \\
(20-88) \\
73 \\
(60-90)\end{array}$ & $\begin{array}{l}55 \\
(45-93) \\
65 \\
(55-70)\end{array}$ & $\begin{array}{l}75 \\
(3-90) \\
28 \\
(11-69)\end{array}$ & $\begin{array}{l}24 \dagger \\
(0-60) \\
27 \\
(10-49)\end{array}$ & $\begin{array}{l}85 \\
(8-90) \\
70 \\
(59-88)\end{array}$ & $\begin{array}{l}44 \dagger \\
\left(\begin{array}{c}0-63) \\
39 \dagger \\
(20-70)\end{array}\right.\end{array}$ & $\begin{array}{l}74 \\
(10-85) \\
77 \\
(15-95)\end{array}$ & $\begin{array}{l}47^{*} \\
\left(\begin{array}{c}8-60) \\
57^{*}\end{array}\right. \\
(13-84)\end{array}$ \\
\hline
\end{tabular}

ADP $=$ adenosine diphosphate. ${ }^{*} \mathrm{p}<0.01 ; \dagger \mathrm{p}<0.05$. $\mathrm{p}$ values obtained by comparing the results of experiments carried out at $37^{\circ} \mathrm{C}$ with those of the paired experiment carried out at $27^{\circ} \mathrm{C}$ (Wilcoxon test). Results are expressed as median (range). 
Plasma $\beta$-thromboglobulin and platelet factor 4 concentrations. Blood was collected in 1/10 volume of an anticoagulant mixture containing EDTA, theophylline, and adenosine (final concentrations $0.013 \mathrm{M}, 0.002 \mathrm{M}$, and $0.001 \mathrm{M}$ respectively). After blood collection, the sample tubes were immediately placed in melting ice. Samples were then centrifuged at $2500 \mathrm{~g}$ for $20 \mathrm{~min}$ at $4^{\circ} \mathrm{C}$. The plasma layer was removed and recentrifuged as before. The middle of the plasma layer was then removed and stored at $-20^{\circ} \mathrm{C}$ until assayed. $\beta$-thromboglobulin and platelet factor 4 were assayed by the double antibody method. ${ }^{9}$

Platelet adenine nucleotides. Platelet adenine nucleotide assays were performed using the firefly method. ${ }^{10}$

\section{EX VIVO STUDIES}

We also attempted to detect changes in platelet function after cooling in vivo.

\section{Patients}

Nine patients were included in this study (two men; seven women; median age 35 years, range 22-58 years). Two patients had primary Raynaud's disease and the other seven had mixed connective tissue disease (three patients) or CREST variation of scleroderma (four patients). These patients had less severe disease and lower plasma $\beta$-thromboglobulin concentrations than those included in the in vitro study since we considered it unethical to expose patients with severe ischaemic lesions of the hands to potential damage by cold injury. All patients admitted to having exposed their hands to low temperatures on previous occasions. Nine healthy controls were also selected as described in the previous section. Informed consent was obtained from all patients.

\section{Experimental procedure}

Blood was collected from a vein in the antecubital fossa as described for the in vitro experiments. The arm was then immersed (up to $3 \mathrm{~cm}$ below the olecranon) for $10 \mathrm{~min}$ in a tank of cold water maintained at $13-15^{\circ} \mathrm{C}$. The arm was then quickly dried, and another blood sample was collected from a different vein in the same arm.

Blood was processed and tests carried out as described for the in vitro experiments. Samples were also collected for measuring circulating platelet aggregates. This test was performed by a modification of the method of Wu and Hoak," the platelet counts being determined visually. The superficial skin temperature was monitored before and after cooling using a digital thermometer (Whitley Scientific Ltd, Shipley, UK), the heat sensi- tive probe being placed on the palmar aspect of the distal end of the ring finger.

\section{STATISTICAL ANALYSIS}

A Mann-Whitney test was used to compare unpaired samples, and a paired Wilcoxon rank sum test was used for paired data. Results are expressed as median and (range).

\section{Results}

\section{IN VITRO STUDIES}

\section{Platelet aggregation}

In conventional platelet aggregation tests carried out at $37^{\circ} \mathrm{C}$, the patients showed a significantly $(p<0.05)$ enhanced response to low dose $(0.5$ $\mu \mathrm{mol} / \mathrm{l})$ adrenaline, but not to $2 \mu \mathrm{mol} / \mathrm{l}$ adrenaline or to ADP, collagen, or ristocetin (Table 1).

With low dose $(0.5 \mu \mathrm{mol} / \mathrm{l})$ ADP there was a significantly greater percentage platelet aggregation at $27^{\circ} \mathrm{C}$ than at $37^{\circ} \mathrm{C}$, both in patients and controls. This phenomenon was not seen at $2 \mu \mathrm{mol} / \mathrm{l}$ or with adrenaline or collagen. Indeed, platelet aggregability in response to these latter agonists was often significantly higher at $37^{\circ} \mathrm{C}$ than at the lower temperature (Table 2).

\section{Thromboxane $B_{2}$ release from platelets}

Although there was no difference between tests carried out at $37^{\circ} \mathrm{C}$ and $27^{\circ} \mathrm{C}$ in the extent of aggregation induced by ADP $(10 \mu \mathrm{mol} / \mathrm{l})$, significantly more thromboxane $B_{2}$ was generated at the higher temperature. This was true both in patients and in controls. Additionally, at $37^{\circ} \mathrm{C}$ but not at $27^{\circ} \mathrm{C}$, significantly more thromboxane $\mathrm{B}_{2}$ was generated in the patient group than in controls (Table 3).

Using collagen $(1 \mu \mathrm{g} / \mathrm{ml})$ as agonist, both the amount of aggregation and the amount of thromboxane $\mathrm{B}_{2}$ generated were significantly greater at $37^{\circ} \mathrm{C}$ than at $27^{\circ} \mathrm{C}$. No difference between patients and controls was found at either temperature.

Inhibitory effect of prostacyclin and prostaglandin $E_{1}$ on platelet aggregation (Table 4)

Inhibition of platelet aggregation was significantly less at $27^{\circ} \mathrm{C}$ than at $37^{\circ} \mathrm{C}$ in all cases except in the patient group tested with a lower dose of prostacyclin $(2 \mathrm{ng} / \mathrm{ml})$. The degree of inhibition of aggregation was always greater in controls than in patients with Raynaud's syndrome and this difference was significant when using prostacyclin $4 \mathrm{ng} / \mathrm{ml}$ at $37^{\circ} \mathrm{C}$ and $27^{\circ} \mathrm{C}$ and with prostaglandin $\mathrm{E}_{1} 20 \mathrm{ng} / \mathrm{ml}$ at $27^{\circ} \mathrm{C}$.

Other in vitro measurements

Patients showed significantly higher plasma 
$\beta$-thromboglobulin concentrations than controls, although the platelet factor 4 concentrations in both groups were similar (Table 1). Plasma fibrinogen concentration was significantly higher $(p<0.002)$ in the patients with Raynaud's syndrome (median $3.5 \mathrm{~g} / \mathrm{l}$ : range $2 \cdot 2-6.2 \mathrm{~g} / \mathrm{l})$ than in the controls $(2 \cdot 4$ $\mathrm{g} / \mathrm{l}: 1 \cdot 5-3 \cdot 1 \mathrm{~g} / \mathrm{l})$, although there was no correlation between plasma fibrinogen concentrations and other indicators of platelet reactivity (aggregation; $\beta$-thromboglobulin; platelet factor 4 ; thromboxane $\mathrm{B}_{2}$ generation). There was no significant difference between the patients and controls in either platelet total adenine nucleotide content or in the ATP: ADP ratio.

EX VIVO STUDIES (Table 5)

There was no significant difference between patients and controls in skin temperature either before or

Table 3 Percentage platelet aggregation and concentration of thromboxane $B_{2}$ released at $37^{\circ} \mathrm{C}$ and $27^{\circ} \mathrm{C}$ in patients with Raynaud's syndrome and in control subjects

\begin{tabular}{|c|c|c|c|c|c|c|c|c|}
\hline & \multicolumn{4}{|c|}{$A D P(10$ rmolll $)$} & \multicolumn{4}{|c|}{ Collagen $(1 \mu \mathrm{g} / \mathrm{ml})$} \\
\hline & \multicolumn{2}{|c|}{ Aggregation (\%) } & \multicolumn{2}{|c|}{$\begin{array}{l}\text { Thromboxane } B_{2} \\
\text { (ng/10 platelets) }\end{array}$} & \multicolumn{2}{|c|}{ Aggregation (\%) } & \multicolumn{2}{|c|}{$\begin{array}{l}\text { Thromboxane } B_{2} \\
\left(n g / 10^{8} \text { platelets }\right)^{2}\end{array}$} \\
\hline & $37^{\circ} \mathrm{C}$ & $27^{\circ} \mathrm{C}$ & $37^{\circ} \mathrm{C}$ & $27^{\circ} \mathrm{C}$ & $37^{\circ} \mathrm{C}$ & $27^{\circ} \mathrm{C}$ & $37^{\circ} \mathrm{C}$ & $27^{\circ} \mathrm{C}$ \\
\hline $\begin{array}{l}\text { Patients } \\
\text { Controls }\end{array}$ & $\begin{array}{l}75 \\
(55-80) \\
75 \\
(61-93)\end{array}$ & $\begin{array}{l}66 \\
(50-73) \\
71 \\
(55-88)\end{array}$ & $\begin{array}{l}7 \cdot 0 \dagger \\
(3 \cdot 3-10 \cdot 1) \\
2 \cdot 2 \\
(1 \cdot 2-4 \cdot 2)\end{array}$ & $\begin{array}{l}0.8^{*} \\
(0-1.4) \\
0.4^{*} \\
(0-0.8)\end{array}$ & $\begin{array}{l}74 \\
(10-85) \\
77 \\
(15-95)\end{array}$ & $\begin{array}{c}47 \\
(8-60) \\
(13-84)\end{array}$ & $\begin{array}{l}16 \cdot 5 \\
(9 \cdot 9-20 \cdot 7) \\
14 \cdot 3 \\
(7 \cdot 9-18 \cdot 3)\end{array}$ & $\begin{array}{l}5 \cdot 7^{*} \\
\left(3 \cdot 8^{-12 \cdot 5)}\right. \\
6 \cdot 8^{*} \\
(3 \cdot 3-10 \cdot 1)\end{array}$ \\
\hline
\end{tabular}

ADP $=$ adenosine diphosphate.

${ }^{*} p<0.01$, comparing results at $37^{\circ} \mathrm{C}$ with those of the paired experiment carried out at $27^{\circ} \mathrm{C}$ (Wilcoxon test).

tp $<0.01$, comparing results of patients with those of controls at the same temperature (Mann-Whitney test).

Results are expressed as median (range).

Table 4 Effect of prostacyclin and prostaglandin $E_{1}$ on platelet aggregation in patients with Raynaud's syndrome and in control subjects

\begin{tabular}{|c|c|c|c|c|c|c|c|c|}
\hline & \multirow{2}{*}{\multicolumn{2}{|c|}{$\begin{array}{l}\text { \% Aggregation } \\
\text { with buffer only }\end{array}$}} & \multicolumn{6}{|c|}{ \% Inhibition of platelet aggregation } \\
\hline & & & \multicolumn{2}{|c|}{ Prostacyclin $(2 \mathrm{ng} / \mathrm{ml})$} & \multicolumn{2}{|c|}{ Prostacyclin (4 $\mathrm{ng} / \mathrm{ml})$} & \multicolumn{2}{|c|}{ Prostaglandin $E_{1}(20 \mathrm{ng} / \mathrm{ml})$} \\
\hline & $37^{\circ} \mathrm{C}$ & $27^{\circ} \mathrm{C}$ & $37^{\circ} \mathrm{C}$ & $27^{\circ} \mathrm{C}$ & $37^{\circ} \mathrm{C}$ & $27^{\circ} \mathrm{C}$ & $37^{\circ} \mathrm{C}$ & $27^{\circ} \mathrm{C}$ \\
\hline $\begin{array}{l}\text { Patients } \\
\text { Controls }\end{array}$ & $\begin{array}{l}80 \\
(60-90) \\
88 \\
(48-90)\end{array}$ & $\begin{array}{l}66 \\
(50-88) \\
70 \\
(58-88)\end{array}$ & $\begin{array}{l}41 \\
(0-88) \\
74 \\
(16-91)\end{array}$ & $\begin{array}{l}35 \\
(0-64) \\
40^{*} \\
(9-55)\end{array}$ & $\begin{array}{l}71 \\
(36-88) \\
898 \\
(72-97)\end{array}$ & $\begin{array}{c}43^{*} \\
(32-67) \\
74^{*} \ddagger \\
(30-93)\end{array}$ & $\begin{array}{c}91 \\
(80-99) \\
95 \\
(88-100)\end{array}$ & $\begin{array}{l}62^{*} \\
(45-87) \\
81^{* \dagger} \\
(73-87)\end{array}$ \\
\hline
\end{tabular}

${ }^{*} \mathrm{p}<0.01$, comparing results at $37^{\circ} \mathrm{C}$ with those of the paired experiment carried out at $27^{\circ} \mathrm{C}$ (Wilcoxon test).

$\dagger \mathrm{p}<0.05$, patients $v$ controls; $\neq \mathrm{p}<0.02$, patients $v$ controls; \&p $<0.002$, patients $v$ controls, at the same temperature (Mann-Whitney test). Results are expressed as median (range).

Table 5 Effect of limb cooling on platelet responses in patients with Raynaud's syndrome and in control subjects

\begin{tabular}{|c|c|c|c|c|}
\hline & \multicolumn{2}{|l|}{ Patients } & \multicolumn{2}{|l|}{ Controls } \\
\hline & Before cooling & After cooling & Before cooling & After cooling \\
\hline $\begin{array}{l}\text { Skin temperature }\left({ }^{\circ} \mathrm{C}\right) \\
\text { Platelet counts (platelet rich plasma) }\left(10^{\circ} / \mathrm{l}\right) \\
\text { Circulating platelet aggregates }(\%) \\
\text { Plasma } \beta \text {-thromboglobulin }(\mathrm{ng} / \mathrm{ml}) \\
\text { Plasma platelet factor } 4(\mathrm{pmol} / \mathrm{ml}) \\
\% \text { platelet aggregation } \dagger \\
\text { ADP } 0 \cdot 2 \mu \mathrm{mo} / 1 \\
\text { ADP } 2 \mu \mathrm{mol} / 1\end{array}$ & $\begin{array}{c}24 \cdot 1 \\
(20 \cdot 0-28 \cdot 7) \\
260 \\
(242-498) \\
26^{*} \\
4-26) \\
36 \\
(17-127) \\
0 \cdot 3 \\
0-0 \cdot 5) \\
10 \\
0-79) \\
38 \\
(23-56)\end{array}$ & $\begin{array}{c}16 \cdot 3 \\
(14 \cdot 3-17 \cdot 4) \\
269 \\
(209-446) \\
18^{*} \\
5-26) \\
32 \\
(11-124) \\
02 \\
0-0 \cdot 6) \\
14 \\
0-80) \\
63 \\
3-90)\end{array}$ & $\begin{array}{c}28 \cdot 8 \\
(24 \cdot 8-31 \cdot 3) \\
247 \\
(180-262) \\
8 \\
(0-10) \\
28 \\
5-70) \\
0-3 \\
0-0 \cdot 7) \\
11 \\
5-18) \\
65 \\
(52-81)\end{array}$ & 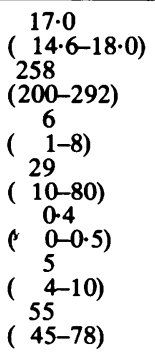 \\
\hline
\end{tabular}

ADP $=$ adenosine diphosphate.

${ }^{*} \mathrm{p}<0.04$ : patients $v$ controls (before cooling $v$ before cooling and after cooling $v$ after cooling) using the Mann-Whitney test. †Platelet aggregation studies were performed in only five patients and five controls.

Results are expressed as median (range). 
after cooling. Of the platelet function indicators measured, only the circulating platelet aggregates were significantly raised in the patients studied. After cooling for 10 min no significant change in any of the platelet variables was detected in the patients or in the controls. We did not see any obvious, sustained, cyanotic phase in the hands of control subjects or patients. Pallor on cooling followed by hyperaemia on rewarming was the usual sequence of events.

\section{Role of age, sex, duration of disease, and type of treatment}

In both in vitro and in vivo experiments there was no obvious relation between age or sex and the results of platelet studies in either patients or controls. The three patients receiving prednisolone had similar responses to those not taking drugs. There was no obvious relation between the duration of disease and the platelet responses.

\section{Discussion}

We have shown that compared with normal subjects, many patients with Raynaud's syndrome have enhanced platelet aggregation in response to a low dose of adrenaline, increased numbers of circulating platelet aggregates, and raised plasma thromboglobulin concentrations. Additional evidence of the increased platelet reactivity was that platelets from patients with Raynaud's syndrome generated significantly more thromboxane $\mathrm{B}_{2}$ than controls after addition of ADP $(10 \mu \mathrm{mol} / \mathrm{l})$ at $37^{\circ} \mathrm{C}$. At $27^{\circ} \mathrm{C}$ there was no difference between controls and patients in either aggregation or thromboxane $B_{2}$ generation and no secondary platelet aggregation occurred, although platelet adenine nucleotide concentrations were normal. This suggests that the enhanced responses seen at $37^{\circ} \mathrm{C}$ were dependent on an augmentation of the biochemical changes which induce the release reaction.

Despite the reduced generation of thromboxane $\mathrm{B}_{2}$ at $27^{\circ} \mathrm{C}$ in both patients and controls, there was greater aggregation at this temperature with low concentrations of ADP when compared with responses at $37^{\circ} \mathrm{C}$. This enhancement of aggregation was not seen with the other agents and was not associated with enhanced release. This phenomenon can probably be attributed to decreased degradation of ADP by temperature dependent ADP-ases in the platelets and plasma. ${ }^{12}$ The fact that this effect was similar in both controls and patients with Raynaud's syndrome is further evidence that the enhanced reactivity of the patients' platelets is due to reinforcement of the release reaction.

A further manifestation of the enhanced reactivity of platelets from patients with Raynaud's syndrome was their greater resistance to the anti-aggregatory effect of prostacyclin and prostaglandin $E_{1}$ (Table 4). We have previously shown ${ }^{67}$ in normal subjects that the inhibitory effects of prostacyclin and prostaglandin $E_{1}$ are less pronounced at $27^{\circ} \mathrm{C}$ than at $37^{\circ} \mathrm{C}$, and this observation is confirmed by the present study. In patients with Raynaud's syndrome, however, the $37^{\circ} \mathrm{C}-27^{\circ} \mathrm{C}$ difference is less apparent at lower doses of prostacyclin (Table 4). This difference may be due to the generally enhanced platelet reactivity in this group, even in the presence of the prostaglandin inhibitors.

Many patients with Raynaud's syndrome had significantly raised plasma fibrinogen concentrations. This observation is compatible with the findings of others..$^{213-15}$ Binding of fibrinogen to platelets occurs during platelet aggregation and during cooling of platelet rich plasma. ${ }^{16}$ Moreover, we have recently shown that the addition of purified human fibrinogen to platelet rich plasma in vitro enhances platelet reactivity to several agonists (unpublished observations). Thus the raised plasma fibrinogen concentration in the patient group may have contributed to the enhanced platelet responses observed.

No significant change was seen in any of the variables measured after cooling either in controls or in patients. This absence of an effect of cooling may have been due to several factors. Firstly, patients with relatively mild Raynaud's syndrome were selected. Secondly, cooling may activate platelets locally but this change may be insufficient to produce a generalised effect. It may also be of relevance that we did not observe a cyanotic phase in the cooled hands of control subjects or patients; only pallor, followed by hyperaemia on rewarming were observed. Finally, cooling may exert a direct local effect on blood vessels, which may not be mediated through platelet activation. ${ }^{17}$ Nevertheless, excessive cooling can induce platelet aggregation in vitro, ${ }^{18}$ and hypothermia in man is associated with increased incidence of vascular lesions, as discussed by us previously. ${ }^{19}$ In addition, application of ice water to healthy volunteers was associated with platelet activation. ${ }^{20}$ In this context we have previously shown that cooling reduces prostacyclin synthesis by vessels. ${ }^{21}$ Cooling also mediates an enhanced vasoconstrictor response of blood vessels to 5-hydroxytryptamine, ${ }^{22}$ a substance released by activated platelets ${ }^{23}$ that can in turn enhance platelet aggregation. ${ }^{24}$ It is therefore of interest that a 0 5-hydroxytryptamine antagonist, ketanserin, antagonises these 5-hydroxytryptamine effects ${ }^{24} 25$ and is beneficial in the treatment of Raynaud's syndrome. ${ }^{26}$ 
The observed, enhanced platelet aggregation and decreased sensitivity to prostacyclin or prostaglan$\operatorname{din} E_{1}$ at lower temperatures may be relevant in the pathogenesis of Raynaud's phenomenon. These "activated" platelets, together with the decreased synthesis of prostacyclin by the vascular endothelium at lower temperatures ${ }^{21}$ may upset the prostacyclin/thromboxane $\mathrm{A}_{2}$ balance favouring the vasoconstrictor and proaggregatory properties of thromboxane $A_{2} .{ }^{s}$ Finally, repetitive trauma or thrombosis affecting the peripheral vascular bed may progressively decrease local prostacyclin production. This hypothesis is compatible with the finding that the administration of exogenous prostacyclin (or other antiaggregatory prostaglandins $)^{27-30}$ improves the condition by reversing some of the changes we have described. There remains a need to explain why the beneficial effect of prostacyclin in these patients lasts for several weeks despite the fact that it is rapidly cleared from the plasma and that its effect on platelet function in vivo is only modest and transient. ${ }^{30}$

\section{Dr DP Mikhailidis is a Wellcome Trust Fellow.}

\section{References}

' Anonymous. Pathophysiology of Raynaud's phenomenon. $\mathrm{Br}$ Med J 1980;281:1027-8.

${ }^{2}$ Blunt RJ, George AJ, Hurlow RA, Strachan CJL, Stuart J. Hyperviscosity and thrombotic changes in idiopathic and secondary Raynaud's Syndrome. Br J Haematol 1980;45:651-8.

${ }^{3}$ Rodnan GP, Myerowitz RL, Justh GO. Morphologic changes in the digital arteries of patients with progressive systemic sclerosis (scleroderma) and Raynaud's phenomenon. Medicine 1980;59:393-408.

4 Moncada S, Vane JR. Prostacyclin: homeostatic regulator or biological curiosity? Clin Sci 1981;61:369-72.

${ }^{5}$ Needleman P, Minkes M, Raz A. Thromboxane selective biosynthesis and distinct biological properties. Science 1976; 193: $163-5$.

- Mikhailidis DP, Hutton RA, Dandona P. Effect of cooling on prostaglandin mediated inhibition of platelet aggregation. Clin Sci 1981;61:28P.

' Mikhailidis DP, Hutton RA, Jeremy JY, Dandona P. Cooling decreases the efficiency of prostaglandin inhibitors of platelet aggregation-a factor of possible relevance in cold induced pathology. Microcirculation 1983;2:413-24.

${ }^{8}$ Ingram GIC. A suggested schedule for the rapid investigation of acute haemostatic failure. J Clin Pathol 1961;14:356-60.

${ }^{9}$ Woodhams BJ, Kernoff PBA. The application of polyethylene glycol to radioimmunoassays used in haemostasis. Thromb Res 1983;29:333-41.

${ }^{10}$ Holmsen H, Holmsen I, Bernhardsen A. Microdetermination of adenosine diphosphate and adenosine triphosphate in plasma with firefly luciferase system. Ann Biochem 1966;17:456-73.

" Wu KK, Hoak JC. A new method for the quantitative detection of platelet aggregation in patients with arterial insufficiency. Lancet 1974;ii:924-6.
12 Holmsen I, Holmsen H. Partial purification and characterisation of an ADP phosphohydrolase from human plasma. Thromb Diath Haemorrh 1971;26:177-91.

13 Johnsen T, Nielsen SL, Skovborg F. Blood viscosity and local response to cold in primary Raynaud's phenomenon. Lancet 1977;ii: 1001-2.

14 Jarret PEM, Morland M, Browse NL. Treatment of Raynaud's phenomenon by fibrinolytic enhancement. $\mathrm{Br}$ Med $J$ 1978;ii:523-5.

is Tietjen GW, Chien S, Leroy EC, Gavras I, Gavras H, Gump FE. Blood viscosity, plasma proteins, and Raynaud's Syndrome. Arch Surg 1975;110:1343-6.

${ }^{16}$ Zucker MB, Peerschke EI. Specific binding of fibrinogen to platelets: relationship to shape change and aggregation. In: Rotman A, Meyer FA, Gitler C, Silberberg A, eds. Platelets cellular response mechanisms and their biological significance. Chichester: J Wiley and Sons, 1980:157.

17 Downey JA, Frewin DB. The effect of cold on blood flow in the hands of patients with Raynaud's phenomenon. Clin Sci 1973;44:279-89.

${ }^{18}$ Kattlove HE, Alexander B. The effect of cold on platelets. I cold-induced platelet aggregation. Blood 1971;38:39-48.

19 Mikhailidis DP, Hutton RA, Jeremy JY, Dandona P. Hypothermia and pancreatitis. J Clin Pathol 1983;36:483-4.

${ }^{20}$ Neri Serneri GG, Abbate R, Gensini GF, Galanti G, Paoli G, Laureano $R$. Platelet aggregation and thromboxane $\mathrm{A}_{2}$ production after adrenergic stimulation in young healthy humans. Haemostasis 1982;11:40-8.

${ }^{21}$ Jeremy JY, Mikhailidis DP, Hutton RA, Dandona P. Effect of cooling on prostacyclin-induced increase in intraplatelet cyclic AMP and on prostacyclin production. Clin Sci 1982;62:42P.

22 Vanhoutte PM, Shepherd JT. Effect of temperature on reactivity of isolated cutaneous veins of the dog. Am J Physiol 1970;218: 187-90.

${ }^{23}$ Best LC, Holland TK, Jones PBB, Russell RGG. The interrelationship between thromboxane biosynthesis, aggregation and 5-hydroxytryptamine secretion in human platelets in vitro. Thromb Haemost 1980;43:38-40.

${ }^{24}$ De Clerck FF, David JL, Janssen PAJ. Serotonergic amplification mechanisms in blood platelets. In: De Clerck F, Vanhoutte PM, eds. 5-Hydroxytryptamine in peripheral reactions. New York: Raven Press, 1982:83-94.

${ }^{25}$ Van Nueten JM, Serotonergic amplification mechanisms in vascular tissues. In: De Clerck F, Vanhoutte PM, eds. 5-Hydroxytryptamine in peripheral reactions New York: Raven Press, 1982:77-82.

${ }^{26}$ Stranden E, Roald OK, Krohg K. Treatment of Raynaud's phenomenon with the 5- $\mathrm{HT}_{2}$-receptor antagonist ketanserin. Br Med J 1982; 285: 1069-71.

${ }^{27}$ Pardy BJ, Hoare MC, Eastcott HHG, et al. Prostaglandin $E_{1}$ in severe Raynaud's phenomenon. Surgery 1982;92:953-65.

${ }^{28}$ Martin MFR, Tooke JE. Effects of prostaglandin $E_{1}$ on microvascular haemodynamics in progressive systemic sclerosis. Br Med J 1982;285:1688-90.

${ }^{29}$ Dowd PM, Kovacs IB, Bland CJH, Kirby JDT. Effect of prostaglandins $I_{2}$ and $E_{1}$ on red cell deformability in patients with Raynaud's phenomenon and systemic sclerosis. $\mathrm{Br}$ Med $\mathrm{J}$ 1981;283:350.

${ }^{30}$ Belch JJF, Newman P, Drury JK, et al. Intermittent epoprostenol (prostacyclin) infusion in patients with Raynaud's syndrome. Lancet 1983;i:313-5.

Requests for reprints to: Dr P Dandona, Metabolic Unit, Department of Chemical Pathology, Royal Free Hospital, Pond Street, London NW3 2QG, England. 